\title{
GIS-Based Irrigation Dams Potential Assessment of Floating Solar PV System
}

\author{
Abraham Hizkiel Nebey (D), Biniyam Zemene Taye, and Tewodros Gera Workineh \\ Lecturer of Electrical Power, Faculty Electrical and Computer Engineering, Bahir Dar University Institute of Technology, \\ Bahir Dar, Ethiopia \\ Correspondence should be addressed to Abraham Hizkiel Nebey; hizkielabraham@yahoo.com
}

Received 8 January 2020; Revised 29 April 2020; Accepted 11 May 2020; Published 31 May 2020

Academic Editor: Mohamed Benghanem

Copyright (C) 2020 Abraham Hizkiel Nebey et al. This is an open access article distributed under the Creative Commons Attribution License, which permits unrestricted use, distribution, and reproduction in any medium, provided the original work is properly cited.

\begin{abstract}
The majority of the Ethiopian population lives in rural areas and uses wood for domestic energy consumption. Using wood and fuel for domestic uses accounts for deforestation and health problems, which is also dangerous for the environment. The Ethiopian government has been planning to generate power from available renewable resources around the community. Therefore, determining the water surface potential of energy harvesting with floating solar photovoltaic system by using geographic information system is used to support decision-makers to use high potential areas. To identify useable areas for floating solar photovoltaic, factors that affect the usability were identified and weighted by using Analytical Hierarchy Processes. Thus, weighted values and reclassified values were multiplied to do the final usability map of floating solar photovoltaic with ArcGIS software. Due to the improper location of floating solar photovoltaic, efficiency is dropped. Therefore, the objective of this study was to identify the most usable surface of water bodies in Amhara regional, state irrigation dams for generating electrical power. The usability of the water surface for floating solar photovoltaic power plant was $63.83 \%, 61.09 \%$, and $57.20 \%$ of Angereb, Rib, and Koga irrigation dams, respectively. The majority of the usable areas were found in the middle of the water surface. Nature water surface is a key factor in generating solar energy; it affects the floating solar photovoltaic and irradiance coming to the solar photovoltaic panel surface.
\end{abstract}

\section{Introduction}

Currently, using promising alternative energy technology to extract maximum power from solar photovoltaic source is a reasonable choice for electrification in Ethiopia. Thus, floating solar PV on the water surface is an ideal solution to improve the technical and economic issue. Solar PV floating is currently emerging technology which uses the surface of the water for power generation. Water bodies like irrigation dams, canals or remediation, water reservoirs, lakes, and ocean are used for floating $[1,2]$. Due to the water surface cooling effect, the floating PV system on the water surface has a lower temperature that reduces the cell temperature of the solar PV panel. Thus, floating solar panel is $11 \%$ more efficient than the land-based solar panels [3-5].

The scarcity of land, efficiency drop at high operating PV cell temperature, and lack of researches on the area are dominant factors that limit the growth of PV penetration in the world and particularly in Ethiopia. Therefore, the combination of solar PV and floating technology on the water surface is the best solution to overcome the above problems [6-8].

Solar PV floating system has environmental benefits like reducing evaporation and improving water quality in addition to the efficiency of the power plant. Panels shading water surface also reduce the growth of algae $[3,9]$.

A country like Ethiopia, where agriculture leads the economy, scarcity of land and food insecurity is critical issues. Floating solar PV technology on the surface water bodies is not a choice. Therefore, the aim of this paper was to assess floating solar PV potential in Amhara regional state [10, 11].

\section{Literature Review}

There are different solar floating-related studies in which the work focused on design concepts of solar floating on water surfaces. And researchers also argued that temperature and 
TABLE 1: Solar PV floating system related studies without multicriteria decision-making perspectives.

\begin{tabular}{|c|c|c|c|c|c|}
\hline No. & Attempt & Method & Weakness & Year & Reference \\
\hline 1 & $\begin{array}{c}\text { Design and construction of } \\
\text { floating PV generation } \\
\text { structure PV }\end{array}$ & GIS approach & $\begin{array}{l}\text { There was multicriteria } \\
\text { decision-making approach to } \\
\text { identify the usable surface of water. }\end{array}$ & 2017 & {$[14]$} \\
\hline 2 & $\begin{array}{c}\text { Floating PV system analysis } \\
\text { by considering environmental impacts }\end{array}$ & $\begin{array}{l}\text { Comparison approaches } \\
\text { were used with some } \\
\text { mathematical modeling } \\
\end{array}$ & It was not georeferenced & 2019 & {$[15]$} \\
\hline 3 & Floating and floating tracking system & $\begin{array}{l}\text { Dynamic technoeconomic } \\
\text { optimization model }\end{array}$ & $\begin{array}{l}\text { GIS system analysis was } \\
\text { not considered }\end{array}$ & 2019 & {$[16]$} \\
\hline 4. & $\begin{array}{l}\text { Floating periodization solar PV } \\
\text { system to land-based installation }\end{array}$ & GIS based & $\begin{array}{l}\text { Multicriteria decision-making } \\
\text { approach was not considered }\end{array}$ & 2019 & {$[17]$} \\
\hline 5. & Economical floating feasibility & $\begin{array}{l}\text { Mathematical modeling } \\
\text { approaches }\end{array}$ & There was no georeferenced system & 2019 & {$[18]$} \\
\hline 6. & $\begin{array}{c}\text { Technical floating } \\
\text { potential assessment }\end{array}$ & Floating system design approach & $\begin{array}{c}\text { There was no specific } \\
\text { cases study area }\end{array}$ & 2019 & [19] \\
\hline
\end{tabular}

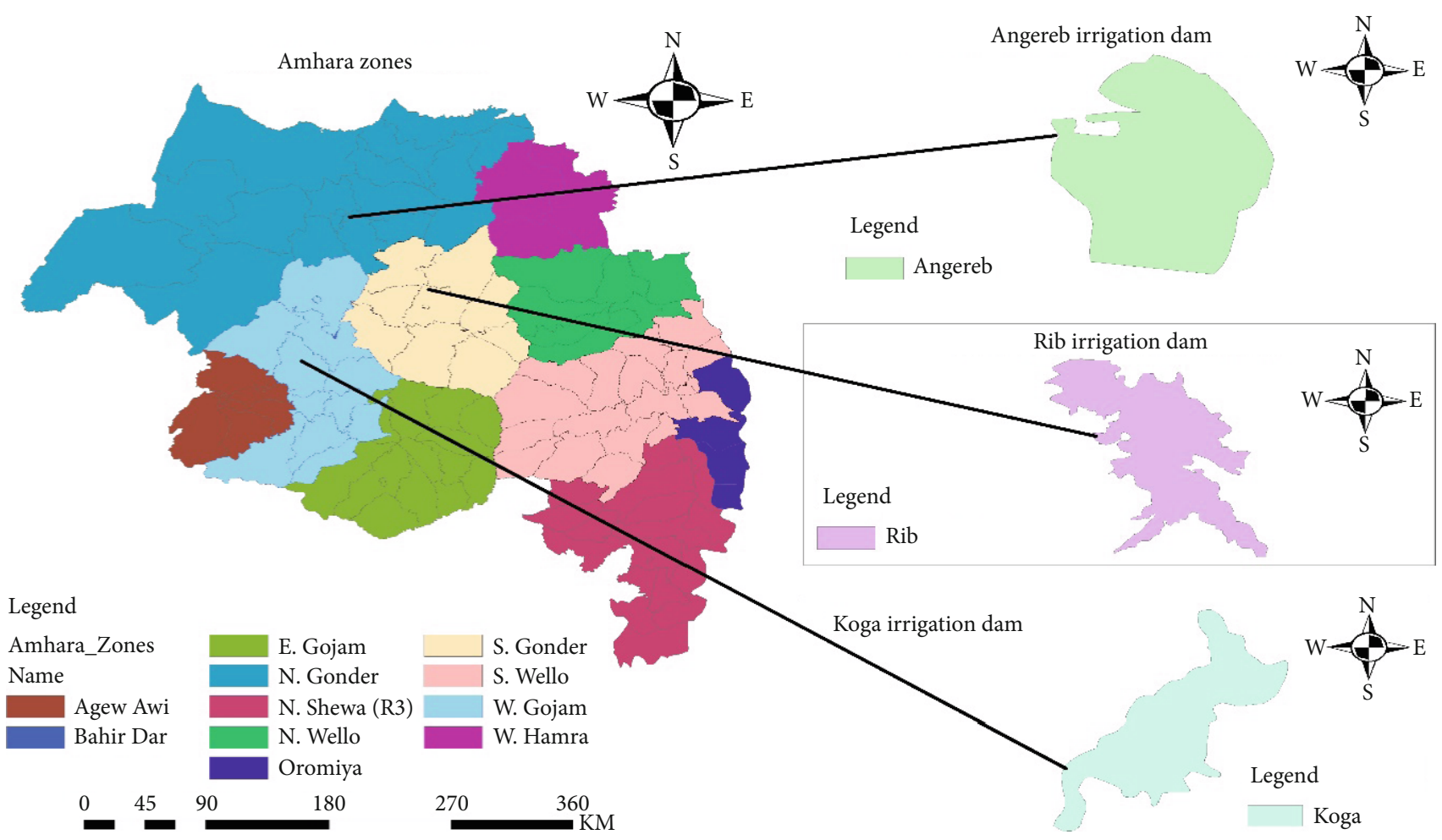

Figure 1: Map of Amhara Region and the irrigation dams.

wind speed are the main factors that affect the panel efficiency. However, there is no usable part of water surface selection related studies. Despite there are different site, suitability-related studies in which multicriteria decisionmaking have been used for different perspectives. Multicriteria decision-making has been used for energy planning and the selection of suitable sites for power plants installation. This multicriteria decision-making method was used to identify usable/suitable parts of water surface in this study.

The multicriteria weights method has been used to sustainable energy development $[12,13]$. Most of the researchers have argued that MCDM approaches are well-suited to address strategic decision-making on multicriteria problems. MCDM methods provide a systemic and actual way to enclose multiple conflicting objectives. Multicriteria decision-making based on multiattribute value functions are used to support sustainable renewable energy development and select usable parts of water bodies for solar panel floating.

Indre Siksnelyte-Butkiene et al. review provided an application of MCDM with GIS methods in photovoltaic potential assessments and suggested that AHP is the most popular method for multiobjective functions. 
TABLE 2: Fundamental scale for pairwise comparisons $[25,26]$.

\begin{tabular}{lcr}
\hline Degree importance & Definition & Explanation \\
\hline 1 & Equal importance & Criteria equally important to the objective \\
3 & Moderate importance & One criterion slightly importance over another \\
5 & Strong importance & One criterion strongly importance than another \\
7 & Very strong importance & One criterion very strongly importance than another \\
9 & Extreme importance & One criterion extreme importance than another \\
$2,4,6,8$ & Intermediate values & A compromise is needed \\
\hline
\end{tabular}

TABLE 3: Decision maker matrix of floating solar PV power plant.

\begin{tabular}{|c|c|c|c|c|c|}
\hline \multicolumn{2}{|c|}{ Criteria } & $\begin{array}{c}1 \\
\text { Distance } \\
\text { from land }\end{array}$ & $\begin{array}{c}2 \\
\text { Surface } \\
\text { area }\end{array}$ & $\begin{array}{c}3 \\
\text { Forest } \\
\text { distance }\end{array}$ & $\begin{array}{c}4 \\
\text { Depth }\end{array}$ \\
\hline 1 & $\begin{array}{l}\text { Distance } \\
\text { from land }\end{array}$ & 1 & 3 & 2 & 4 \\
\hline 2 & Surface area & $1 / 3$ & 1 & $1 / 2$ & 2 \\
\hline 3 & $\begin{array}{c}\text { Forest } \\
\text { distance }\end{array}$ & $1 / 2$ & 2 & 1 & 3 \\
\hline 4 & Depth & $1 / 4$ & $1 / 2$ & $1 / 3$ & 1 \\
\hline
\end{tabular}

Pilar Díaz-Cuevas et al. used the AHP method to map the potential of solar and wind for home system in Spain.

All the researchers (Table 1) have developed solar PV floating system to obtain optimal power from the solar panels. However, some of the raised approaches require knowledge to adapt multicriteria decision-making. The problem of unconstrained solar PV placement on the water surfaces has been observed. In this study, efficient power harvesting option from solar panel was developed by considering constraints like distance from land, surface area of water body/shape, distance from forest, and depth of water bodies.

\section{Methods}

The meteorological data is collected from NASA surface meteorology. The criteria are set to find the usable area to assess the solar energy potential of those irrigation dams, and finally, ArcMap 10.4.1 is used to show optimal usable area for solar energy generation based on the given criteria $[20,21]$.

3.1. Study Area. Irrigation dams in Amhara regional state were selected for this study. Amhara regional state is one of the nine regional stats located in the north-west part of Ethiopia between $9^{\circ} 20^{\prime}$ and $14^{\circ} 20^{\prime}$ north latitude and $36^{\circ} 20^{\prime}$ and $40^{\circ} 20^{\prime}$ east longitude. The area of the region is estimated about 170,000 square kilometers [22-24]. The region consists large water bodies which are currently using for generating hydroelectric power and for irrigation. Koga, Rib, and Angereb are the irrigation dams constructed in the region (Figure 1).

Koga dam and irrigation project lies in the Tana Basin in the west Gojjam Zone at $11^{\circ} 24^{\prime} 31^{\prime \prime}$ north latitude and $37^{\circ} 9^{\prime}$ $39^{\prime \prime}$ east longitude. It is located adjacent to the town Merawi in Mecha Woreda, $35 \mathrm{~km}$ from Bahir Dar which is the capital
TABLE 4: Normalized decision matrix of floating solar PV power plant.

\begin{tabular}{|c|c|c|c|c|c|}
\hline \multicolumn{2}{|c|}{ Criteria } & $\begin{array}{c}1 \\
\text { Distance } \\
\text { from land }\end{array}$ & $\begin{array}{c}2 \\
\text { Surface } \\
\text { area }\end{array}$ & $\begin{array}{c}3 \\
\text { Forest } \\
\text { distance }\end{array}$ & $\begin{array}{c}4 \\
\text { Depth }\end{array}$ \\
\hline 1 & $\begin{array}{l}\text { Distance } \\
\text { from land }\end{array}$ & 0.480 & 0.462 & 0.522 & 0.4 \\
\hline 2 & $\begin{array}{c}\text { Surface } \\
\text { area }\end{array}$ & 0.160 & 0.154 & 0.130 & 0.2 \\
\hline 3 & $\begin{array}{c}\text { Forest } \\
\text { distance }\end{array}$ & 0.240 & 0.308 & 0.261 & 0.3 \\
\hline 4 & Depth & 0.120 & 0.077 & 0.087 & 0.1 \\
\hline
\end{tabular}

TABLE 5: Eigenvector and weights of the criteria floating solar PV attributes.

\begin{tabular}{lccc}
\hline \multicolumn{2}{l}{$\begin{array}{l}\text { Criteria for suitability } \\
\text { analysis }\end{array}$} & Eigenvector & Weight \\
\hline 1 & Distance from land & 1.863 & 0.466 \\
2 & Surface area & 0.644 & 0.161 \\
3 & Forest distance & 1.109 & 0.277 \\
4 & Depth & 0.384 & 0.096 \\
\hline
\end{tabular}

city of Amhara Regional State. It covers an area of $13.9995 \mathrm{~km}^{2}$ [25].

$\mathrm{Rib}$ dam and irrigation project is situated in the South Gondar Zone of Amhara Regional State at $12.031^{\circ}$ north latitude and $38.008^{\circ}$ east longitude, and it covers an area of $10.6858 \mathrm{~km}^{2}$ [26].

Angereb dam is situated in the Central Gondar Zone of Amhara Regional State at $12.613^{\circ}$ north latitude and $37.486^{\circ}$ east longitude near to the town of Gondar, and it covers an area of $0.3701 \mathrm{~km}^{2}$ [27]. The primary use of the dam is for drinking water, and its secondary use is for irrigation.

3.2. Analytic Hierarchy Process (AHP) for Criteria Evaluation. Analytic Hierarchy Process (AHP) is one of the multicriteria decision-making method $[28,29]$. It is a method to derive ratio scales from paired comparisons. Thus, a pairwise comparison method was used to make complex decision problems in this study. The input was obtained from the actual measurement and subjective opinion like satisfaction feelings and preference [30-32]. Pairwise comparison of the attributes makes it easy to decisions for complex problems. With this method, the importance of the two attributes is compared at one time (Table 2). 


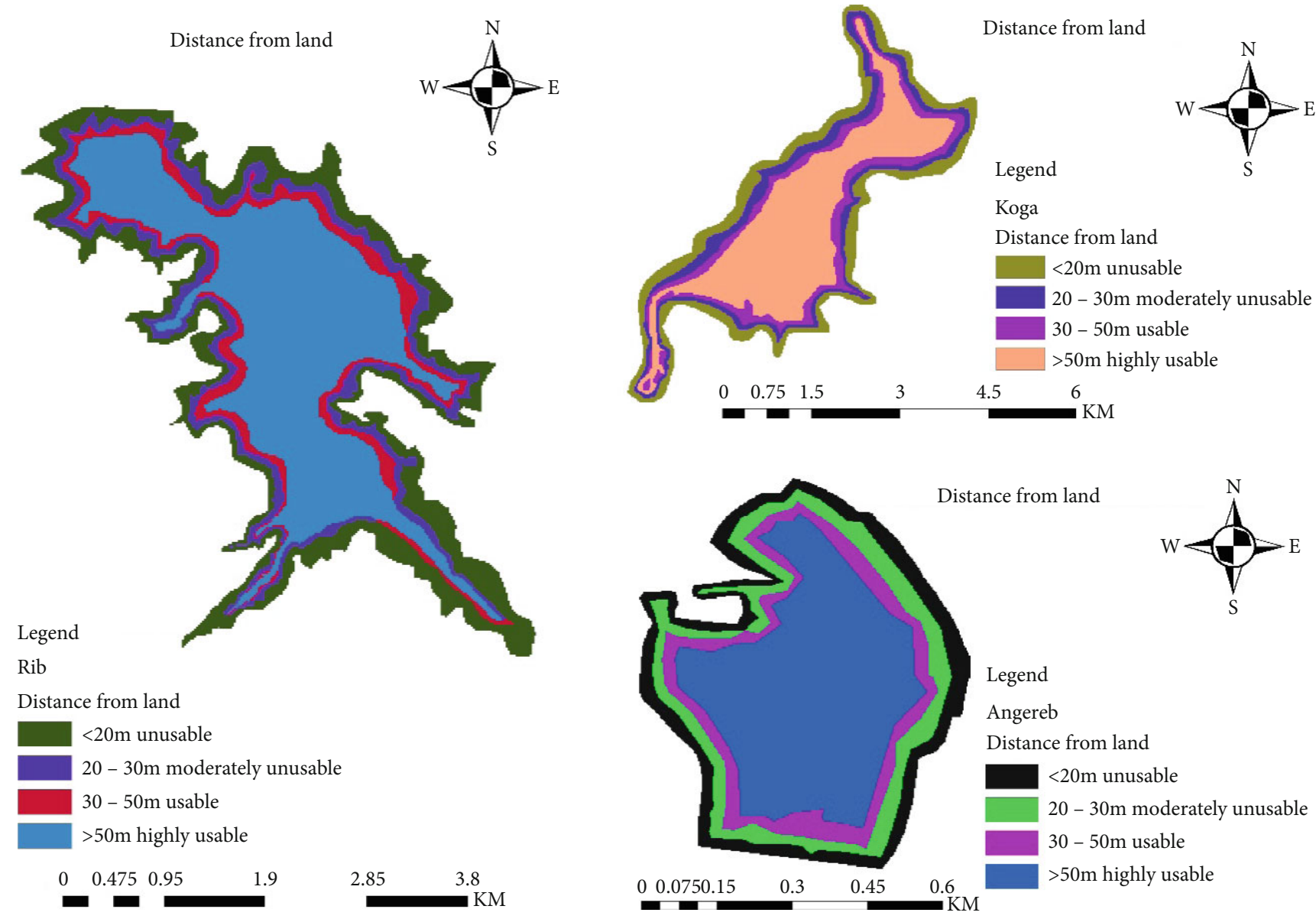

Figure 2: Suitable distance from land.

\subsection{Selecting Criteria for Solar PV on Water Bodies}

\subsubsection{Selection Criteria for Floating Solar PV on Water} Surfaces. In determining the usable and suitable locations for floating solar PV power plant, location to float panel is depending on the weights of each layer $[32,35,36]$. Experts' opinions were used to determine each location criterion for locating floating solar PV on the water surface. Area, depth, distance from land, and distance from the forest were used to formulate a model to determine usable and suitable locations for floating solar PV as per the nature of the water surfaces (Table 3 ).

A normalized decision matrix of floating solar PV power plant is obtained by summing up the column and divides it to each cell value (Table 4). The normalized values are calculated from the decision-making matrix (Aij) as:

$$
N=\frac{\sum j}{c}
$$

where $N$ is normalized value. $J$ is the column of the matrix. $C$ is the values of the column of the decision.

In identifying the potential location for solar PV power plant, location selection was depending on the weights of each layer (Table 5). The weights of the criteria were calculated from the normalized matrix $(\mathrm{Anm})$ as:

$$
W=\frac{\sum n}{X}
$$

where $W$ is the weights of the criteria. $n$ is the row values of normalized matrix. $x$ is the number of criteria for suitability analysis.

3.3.2. Useable Surface of Water Body Analysis of Floating Solar PV. Geographic information system (GIS) is used to indicate the appropriate locations for floating solar PV power plant. ArcGIS prioritizes the location on the surface of the water to determine the most usable surface based on the relative importance [7, 21, 37]. GIS is used to model, store data, analyze data, and display spatial data with the map.

To identify the most usable areas for floating solar PV placement, four data sets were taken as a layer. Thus, dataset were area, depth, distance from land, and distance from forest. The water surface was ranked to identify the most usable locations, and the potential locations for floating solar PV placement were ranked, as highly usable, usable, moderately usable, and unusable. 


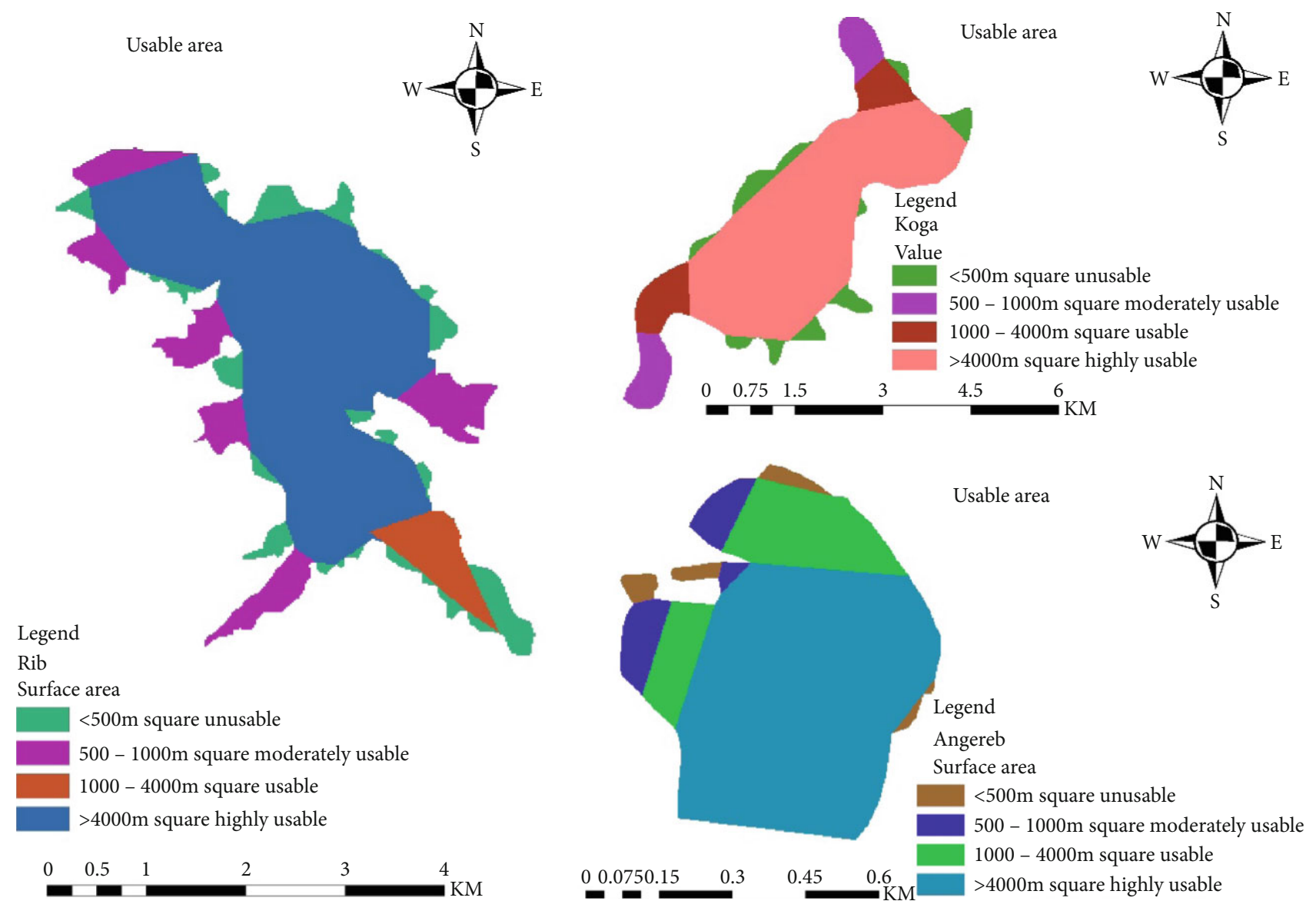

FIgURE 3: Suitable surface area of water for floating solar PV.

3.3.3. Distance from Land Reclassified. Deconstructive actions are important factors that affect any solar PV power plant $[20,31,38,39]$. On land installation, solar PV power plant is protected by a fence; it is difficult to build the fence on the surface of water. Thus, the areas near to land are technically and infeasible and unusable. Therefore, areas less distance than $20 \mathrm{~m}$ was selected as unusable locations for floating solar PV. Water body areas with distance $(20-30 \mathrm{~m})$ moderately usable, $(30-50 \mathrm{~m})$ usable, and greater $50 \mathrm{~m}$ highly usable were prioritized, respectively (Figure 2).

3.3.4. Surface Area Water Bodies Reclassification. The surface area of the water bodies was the most important factor in deterring usable locations for floating solar power plant. The surface irregularity affects the receiving radiation from the sun and power plant installation $[3,5,20,40]$. Thus, regular surface areas receive more radiation and produce more energy from floating solar PV. In addition to the irregular surface, there is no enough area to install solar panels.

Surface areas greater than 4000 meters square were reclassified as highly usable, 1000-4000 meters square were usable, 500-1000 meters square were moderately usable, and less than 500 meters square were unusable (Figure 3).

3.3.5. Forest Distance from Water Bodies Reclassification. Water surface distance from the forest was the most impor- tant factor for floating solar PV power plant location selection. Forest shadow highly affects solar radiation [29, 4042]. Thus, far distance from the forest was considered as the most usable, and the nearest distance was considered as unusable locations.

The forest dataset was reclassified into four classes in this study, greater than $(60 \mathrm{~m})$ highly usable, (40-60) usable, (20$40 \mathrm{~m})$ moderately usable, and less than $(20 \mathrm{~m})$ unusable (Figure 4).

3.3.6. Depth Water Surface Reclassification. The depth of water surface affects floating of panels on the surface of the water $[38,43,44]$. The most depth locations were the most usable locations to float panels easily. The depth was reclassified into four main categories. The more depth locations were taken as more usable locations (Figure 5). The depth greater than $(4 \mathrm{~m})$ highly usable, $(3-4 \mathrm{~m})$ usable, $(2-3 \mathrm{~m})$ moderately usable, and less than $2 \mathrm{~m}$ was unusable, respectively.

\subsection{Weighted Overlays of Floating Solar PV Usability} Analysis. ArcGIS10.4.1 weight overlay tool was used to combine the weights of all criteria. Distance from land, surface area, distance from forest, and depth of water surface dataset were overlaid to the aggregate base on its weight (Figure 6). 

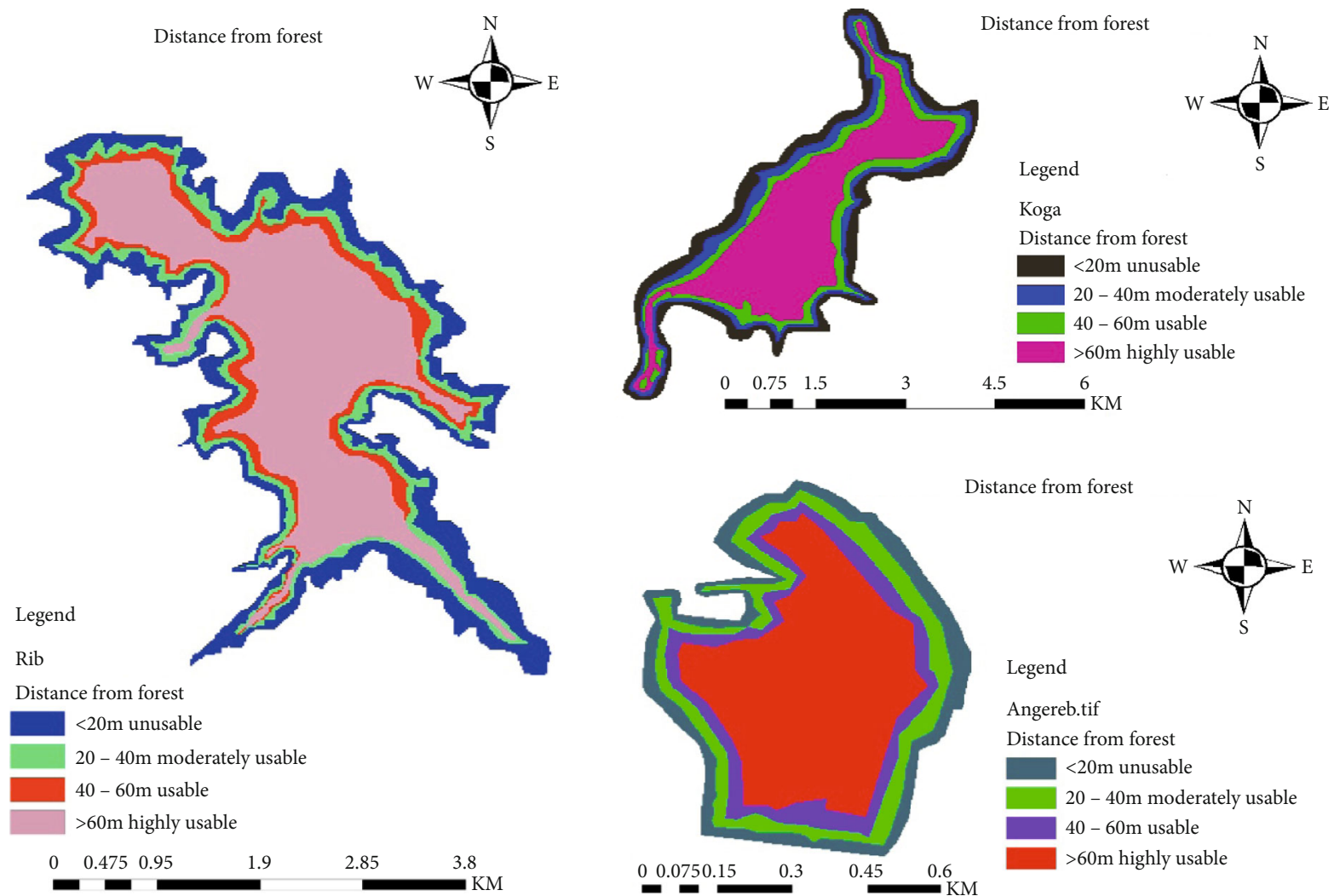

FIGURE 4: Suitable distance of forest floating solar PV.
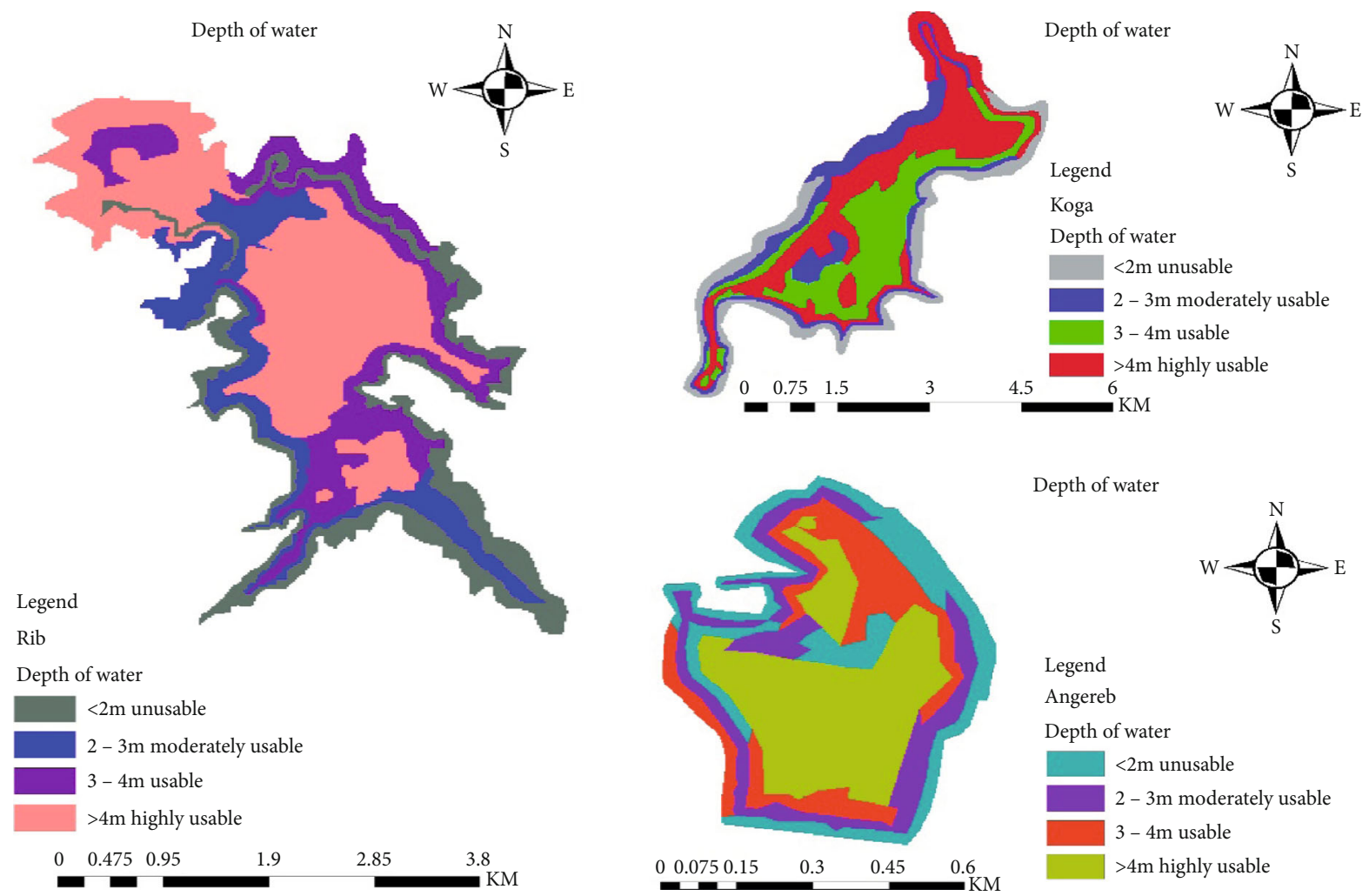

Figure 5: Suitable depth of water surface for floating solar PV. 

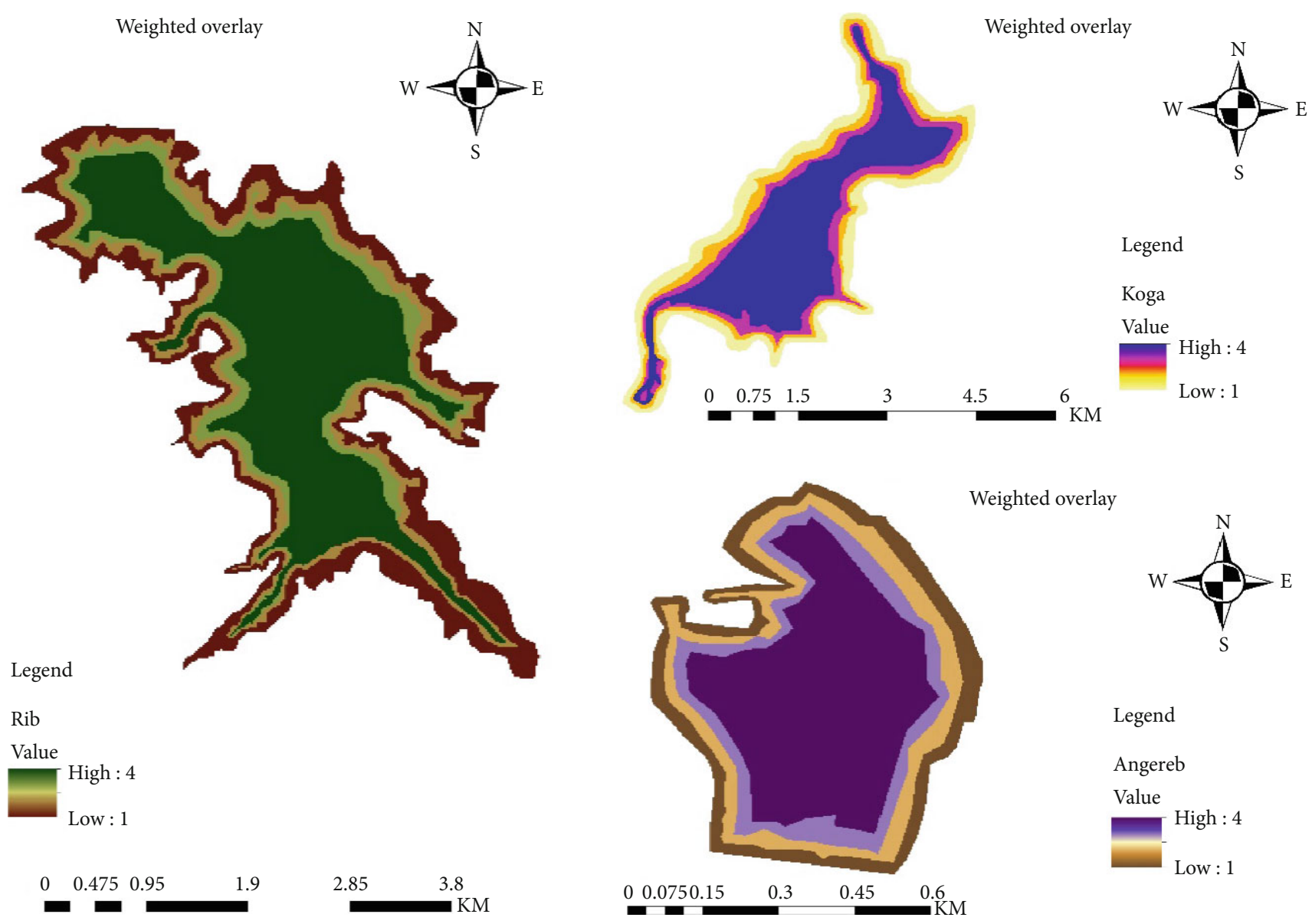

Figure 6: Overall suitability map of floating solar PV.

TABLE 6: Water surface area usability for floating solar photovoltaic in percent.

\begin{tabular}{|c|c|c|c|c|c|c|}
\hline \multirow[t]{2}{*}{ Suitability rank } & Area $\left(\mathrm{m}^{2}\right)$ & Area (\%) & \multirow[t]{2}{*}{ Area $\left(\mathrm{m}^{2}\right)$} & \multirow[t]{2}{*}{ Area (\%) } & Area $\left(\mathrm{m}^{2}\right)$ & Area (\%) \\
\hline & \multicolumn{2}{|c|}{ Angereb } & & & \multicolumn{2}{|c|}{ Koga } \\
\hline Unusable & 69921.89 & 18.89 & 3375597.89 & 24.11 & 3084778.60 & 28.87 \\
\hline Moderately usable & 63973.87 & 17.28 & 2072640.31 & 14.80 & 1487507.06 & 13.92 \\
\hline Usable & 55726.45 & 15.05 & 2118449.10 & 15.13 & 1082442.05 & 10.13 \\
\hline Highly usable & 180592.32 & 48.78 & 6434451.26 & 45.96 & 5028777.965 & 47.07 \\
\hline Total & 370214.53 & 100.00 & 14001138.55 & 100.00 & 10683505.68 & 100.00 \\
\hline
\end{tabular}

The final map of usable surface area water was obtained by multiplying reclassified value with each weight value and adding up all layer products [35, 45-48]. The rank of floating solar PV usability was from one to four. Thus, surface water was divided into four main categories, and a highly usable water surface for placing floating solar PV value was one (Table 6).

3.5. Solar Photovoltaic Potential Analysis. Three irrigation dams were selected in Amhara regional state (Figure 1) for this study. To obtain the irrigation dam potential values of power generation, Monocrystalline silicon module HCP78X9-400 W (Table 7) was selected. The dimension $(L \times W \times T)$ of selected PV panel is $2172 \times 1002 \times 40 \mathrm{~mm}$.
The highly usable and usable area (Table 6) of water surface was considered as a suitable area for floating PV power generations (Table 8). Thus, power output was determined by dividing usable area to single panel area and then multiplied by panel power rating the efficiency of the selected panel.

\section{Result and Discussion}

The middle parts of water surface were usable for floating solar PV from the eligible water surface. This is due to the long distance from land, large and irregular area of water surface, far distance from forest, and far from forest, and more depth of water. In addition to middle part of water surface, 
TABLE 7: Solar photovoltaic specification $[41,42]$.

\begin{tabular}{lc}
\hline Module type & HCP78X9-400 W \\
\hline Maximum power $P_{\text {max }}$ & $400 \mathrm{~W}$ \\
Open-circuit voltage $V_{o c}$ & $51.6 \mathrm{~V}$ \\
Maximum power voltage $V_{m p}$ & $42.0 \mathrm{~V}$ \\
Short-circuit current $I_{s c}$ & $9.95 \mathrm{~A}$ \\
Maximum power current $I_{m p}$ & $9.53 \mathrm{~A}$ \\
Module efficiency (\%) & $18.38 \%$ \\
Power tolerance & $0 \sim+5 \mathrm{~W}$ \\
Temperature coefficient of $I_{s c}$ & $0.05 \% /{ }^{\circ} \mathrm{C}$ \\
Temperature coefficient of $V_{o c}$ & $-0.31 \% /{ }^{\circ} \mathrm{C}$ \\
Temperature coefficient of $P_{\max }$ & $-0.38 \% /{ }^{\circ} \mathrm{C}$ \\
Standard test environment & Irradiance $1000 \mathrm{~W} / \mathrm{m}^{2}$, \\
& cell temperature $25^{\circ} \mathrm{C}$, \\
& Spectrum $\mathrm{AM} 1.5$ \\
\hline
\end{tabular}

TABLE 8: Usable water surface area in percent generation power potential of each irrigation dam.

\begin{tabular}{lccc}
\hline Place & Usable area $\left(\mathrm{m}^{2}\right)$ & Usable area $(\%)$ & Pout $(\mathrm{MW})$ \\
\hline Angereb & 236318.78 & 63.83 & 7.9832 \\
Rib & 6111220 & 57.20 & 206.4457 \\
Koga & 8552900.35 & 61.09 & 288.9292 \\
\hline
\end{tabular}

there were some floating solar potential areas nearest to the land. The majority of unusable areas were found near to land due to short distance from the forest and low depth (Figure 1).

$63.83 \%, 61.09 \%$, and $57.20 \%$ of water surface areas were highly usable (Table 5) and usable water surface of Angereb, Rib, and Koga irrigation dams, respectively. 17.28\%, 14.80\%, and $13.92 \%$ were moderately usable, and 18.98\%, 24.11, and 28.87 were unusable areas for Angereb, Rib, and Koga, respectively.

\section{Conclusion}

There were higher potentials of floating solar power generation in the Amhara region, irrigation dams, particularly in Rib, Angereb, and Koga. This potential contributes to fill the need of energy the country. It bridges the energy gap of rural and urban communities, if the country uses this high green floating solar photovoltaic potential to generate power.

The majority of water surface fulfilled the usability analysis criteria. Distance from land, distance from forest, water surface area, and depth were the dominant factors for floating solar PV power location usability analysis. To increase rural electrification by finding the optimal locations for floating solar PV, educating the community and stakeholders to change their perception were on renewable energy and related traditional practices like deforestation, and it is on the environment.

\section{Data Availability}

Data to support this study are available, and correspondence author can be contacted for further.

\section{Ethical Approval}

Ethical approval of the study was obtained from Bahir Dar University, Faculty of Electrical and Computer Engineering of Electrical power ethical review committee. The ethical letter was submitted to Bahir Dar, Ethiopia, electric power Utility (Main office), and permission was obtained to conduct the study. To ensure confidentiality, employee's information was kept and was not exposed to third body. Verbal consent was taken, and it was approved by an ethical review committee.

\section{Conflicts of Interest}

The authors declare that there no conflict of interest in regards to the publication of this paper.

\section{Acknowledgments}

Our deepest gratitude goes to Bahir Dar University Institute of Technology, Faculty of Electrical and Computer engineering for giving this chance to conduct this research. The authors are grateful to all friends for particularly supporting this article.

\section{References}

[1] D. R. Aryani, T. A. Khairurraziq, G. R. Ramadhan, N. S. Wardana, F. Husnayain, and I. Garniwa, "Simulation of standalone floating photovoltaic and battery systems," IOP Conference Series: Materials Science and Engineering, vol. 673, p. 012059, 2019.

[2] W. Ke, G. Fang, Q. Liu et al., "Low-temperature solutionprocessed tin oxide as an alternative electron transporting layer for efficient perovskite solar cells," Journal of the American Chemical Society, vol. 137, no. 21, pp. 6730-6733, 2015.

[3] A. Sahu, N. Yadav, and K. Sudhakar, "Floating photovoltaic power plant: a review," Renewable and Sustainable Energy Reviews, vol. 66, pp. 815-824, 2016.

[4] E. Skoplaki and J. A. Palyvos, "On the temperature dependence of photovoltaic module electrical performance: a review of efficiency/power correlations," Solar Energy, vol. 83, no. 5, pp. 614-624, 2009.

[5] K. Zhang, Z. L. Wang, and Y. Yang, "Enhanced P3HT/ZnO nanowire array solar cells by pyro-phototronic effect," ACS Nano, vol. 10, no. 11, pp. 10331-10338, 2016.

[6] Y.-K. Choi, N.-H. Lee, and K.-J. Kim, "Empirical research on the efficiency of floating PV systems compared with overland PV systems," in Proceedings, The 3rd International Conference on Circuits, Control, Communication, Electricity, Electronics, Energy, System, Signal and Simulation, vol. 25, pp. 284-289, 2013.

[7] N. M. Kumar, J. Kanchikere, and P. Mallikarjun, "Floatovoltaics: towards improved energy efficiency, land and water management," International Journal of Civil Engineering and Technology, vol. 9, pp. 1089-1096, 2018. 
[8] N. Yadav, M. Gupta, and K. Sudhakar, "Energy assessment of floating photovoltaic system," in 2016 International Conference on Electrical Power and Energy Systems (ICEPES), pp. 264-269, Bhopal, India, 14-16 Dec. 2016.

[9] T. S. Hartzell, Evaluating Potential for Floating Solar Installations on Arizona Water Management Infrastructure, 2016.

[10] C. Hadley, D. Lindstrom, F. Tessema, and T. Belachew, "Gender bias in the food insecurity experience of Ethiopian adolescents," Social Science \& Medicine, vol. 66, no. 2, pp. 427-438, 2008.

[11] S. T. Feleke, R. L. Kilmer, and C. H. Gladwin, "Determinants of food security in Southern Ethiopia at the household level," Agricultural Economics, vol. 33, no. 3, pp. 351-363, 2005.

[12] A. Kumar, B. Sah, A. R. Singh et al., "A review of multi criteria decision making (MCDM) towards sustainable renewable energy development," Renewable and Sustainable Energy Reviews, vol. 69, pp. 596-609, 2017.

[13] H.-C. Lee and C.-T. Chang, "Comparative analysis of MCDM methods for ranking renewable energy sources in Taiwan," Renewable and Sustainable Energy Reviews, vol. 92, pp. 883896, 2018.

[14] S.-H. Kim, S.-J. Yoon, and W. Choi, "Design and construction of $1 \mathrm{MW}$ class floating PV generation structural system using FRP members," Energies, vol. 10, no. 8, p. 1142, 2017.

[15] Y.-K. Choi, "A study on power generation analysis of floating PV system considering environmental impact," International journal of software engineering and its applications, vol. 8, no. 1, pp. 75-84, 2014.

[16] P. E. Campana, L. Wästhage, W. Nookuea, Y. Tan, and J. Yan, "Optimization and assessment of floating and floatingtracking PV systems integrated in on- and off-grid hybrid energy systems," Solar Energy, vol. 177, pp. 782-795, 2019.

[17] S.-M. Kim, M. Oh, and H.-D. Park, "Analysis and prioritization of the floating photovoltaic system potential for reservoirs in Korea," Applied Sciences, vol. 9, no. 3, p. 395, 2019.

[18] A. K. Singh, D. Boruah, L. Sehgal, and A. P. Ramaswamy, "Feasibility study of a grid-tied 2MW floating solar PV power station and e-transportation facility using 'SketchUp Pro' for the proposed smart city of Pondicherry in India," Journal of Smart Cities, vol. 2, no. 2, 2017.

[19] R. S. Spencer, J. Macknick, A. Aznar, A. Warren, and M. O. Reese, "Floating photovoltaic systems: assessing the technical potential of photovoltaic systems on man-made water bodies in the continental United States," Environmental Science \& Technology, vol. 53, no. 3, pp. 1680-1689, 2018.

[20] F. C. Prinsloo, Development of a GIS-Based Decision Support Tool for Environmental Impact Assessment and DueDiligence Analyses of Planned Agricultural Floating Solar Systems, 2019.

[21] V. Parikh, C. Desai, D. Joshi, and G. Nagababu, "Estimation of electricity generation potential by solar radiation on Sardar Sarovar dam," Energy Procedia, vol. 158, pp. 167-172, 2019.

[22] S. B. Awulachew, A. D. Yilma, M. Loulseged, W. Loiskandl, M. Ayana, and T. Alamirew, Water Resources and Irrigation Development in Ethiopia, 2007.

[23] I. Eguavoen, S. D. Derib, T. T. Deneke, M. McCartney, B. A. Otto, and S. S. Billa, "Digging, Damming or Diverting? Small-Scale Irrigation in the Blue Nile Basin, Ethiopia," Water Alternatives, vol. 5, no. 3, 2012.
[24] G. G. Haile and A. K. Kasa, "Irrigation in Ethiopia: a review," Academia Journal of Agricultural Research, vol. 3, no. 10, pp. 264-269, 2015.

[25] T. Alemayehu, “Smallholder farmer's willingness to pay for improved irrigation water: a contingent valuation study in Koga irrigation project, Ethiopia," Journal of Economics and Sustainable Development, vol. 5, no. 19, pp. 5-15, 2014.

[26] B. Agumas, A. Abewa, and D. Abebe, "Response of irrigated onion (Allium cepa L.) to nitrogen and phosphorus fertilizers at Ribb and Koga irrigation schemes in Amhara region, North Western Ethiopia," International Research Journal of Agriculture and Soil Science, vol. 4, no. 5, pp. 95-100, 2014.

[27] K. M. Estifanos, Water Supply Dams in Ethiopia and Sustainability, 2015.

[28] G. Kannan, A. N. Haq, P. Sasikumar, and S. Arunachalam, "Analysis and selection of green suppliers using interpretative structural modelling and analytic hierarchy process," International Journal of Management and Decision Making, vol. 9, no. 2, pp. 163-182, 2008.

[29] R. Venkata Rao, "Vendor selection in a supply chain using analytic hierarchy process and genetic algorithm methods," International Journal of Services and Operations Management, vol. 3, no. 3, pp. 355-369, 2007.

[30] M. Abdel-Basset, M. Mohamed, and F. Smarandache, "An extension of neutrosophic AHP-SWOT analysis for strategic planning and decision-making," Symmetry, vol. 10, no. 4, p. 116, 2018.

[31] J. Roy, K. Chatterjee, A. Bandyopadhyay, and S. Kar, "Evaluation and selection of medical tourism sites: a rough analytic hierarchy process based multi-attributive border approximation area comparison approach," Expert Systems, vol. 35, no. 1, p. e12232, 2018.

[32] C.-W. Chang, C.-R. Wu, C.-T. Lin, and H.-C. Chen, "An application of AHP and sensitivity analysis for selecting the best slicing machine," Computers \& Industrial Engineering, vol. 52, no. 2, pp. 296-307, 2007.

[33] J. Fülöp, W. W. Koczkodaj, and S. J. Szarek, “A different perspective on a scale for pairwise comparisons," Transactions on computational collective intelligence I: Springer, pp. 71-84, 2010.

[34] T. L. Saaty, "Deriving the AHP 1-9 Scale from First Principles," ISAHP 2001 Proceedings, Bern, Switzerland, 2001.

[35] Y. Choi, J. Suh, and S.-M. Kim, "GIS-Based Solar Radiation Mapping, Site Evaluation, and Potential Assessment: A Review," Applied Sciences, vol. 9, no. 9, p. 1960, 2019.

[36] P. Choudhary and R. K. Srivastava, "Sustainability perspectives-a review for solar photovoltaic trends and growth opportunities," Journal of Cleaner Production, vol. 227, pp. 589-612, 2019.

[37] K. R. Lee and W. H. Lee, "Floating photovoltaic plant location analysis using GIS," Journal of Korean Society for Geospatial Information System, vol. 24, no. 1, pp. 51-59, 2016.

[38] D. B. Portier and J. W. Van Sonsbeek, "Water Intake System and Floating Vessel Equipped with Such a System," Ed: Google Patents, 2019.

[39] F. Prinsloo and G. Prinsloo, "Development of a custom designed GIS-based environmental decision support tool to address water energy nexus issues in floating solar environmental impact assessment," in International Association of Impact Assesment South Africa IAIAsa, vol. 8, pp. 1-11, Goudini, Cape Town, 2017. 
[40] A. Ibrahim, "Effect of shadow and dust on the performance of silicon solar cell," Journal of Basic and applied scientific research, vol. 1, no. 3, pp. 222-230, 2011.

[41] M. J. Adinoyi and S. A. M. Said, "Effect of dust accumulation on the power outputs of solar photovoltaic modules," Renewable Energy, vol. 60, pp. 633-636, 2013.

[42] R. W. Andrews, A. Pollard, and J. M. Pearce, "The effects of snowfall on solar photovoltaic performance," Solar Energy, vol. 92, pp. 84-97, 2013.

[43] T. Perdrizet et al., "Floating Mounting Having a DepthVariable Horizontal Cross-Section," Ed: Google Patents, 2019.

[44] D. V. Evans and R. Porter, "Wave scattering by narrow cracks in ice sheets floating on water of finite depth," Journal of Fluid Mechanics, vol. 484, pp. 143-165, 2003.

[45] Y. Tang, H. Sun, Q. Yao, and Y. Wang, "The selection of key technologies by the silicon photovoltaic industry based on the Delphi method and AHP (analytic hierarchy process): case study of China," Energy, vol. 75, pp. 474-482, 2014.

[46] J. Suh and J. Brownson, "Solar farm suitability using geographic information system fuzzy sets and analytic hierarchy processes: case study of Ulleung Island, Korea," Energies, vol. 9, no. 8, p. 648, 2016.

[47] N. Yeh, P. Yeh, and Y.-H. Chang, "Artificial floating islands for environmental improvement," Renewable and Sustainable Energy Reviews, vol. 47, pp. 616-622, 2015.

[48] J. Palm, V. Probst, A. Brummer et al., "CIS module pilot processing applying concurrent rapid selenization and sulfurization of large area thin film precursors," Thin Solid Films, vol. 431-432, pp. 514-522, 2003.

[49] N. J. Gala, Design and Modeling of Solar Photovoltaic Systems, California State University, Northridge, 2019.

[50] O. Eseosa and O. Kingsley, "Performance evaluation of proposed grid connected solar photovoltaic system for engineering faculty, University of Port Harcourt," Journal of Asian Scientific Research, vol. 9, no. 12, pp. 204-216, 2019. 